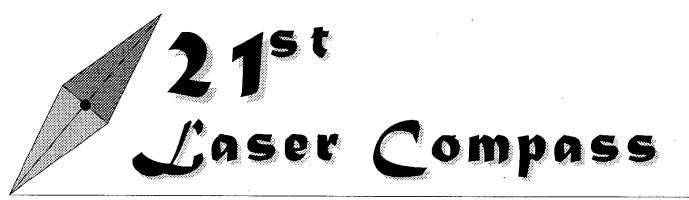

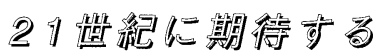

\author{
パワーフォトニクスの展開 \\ 中塚 正大 \\ 大阪大学 レーザー核融合研究センター（テ565-0871 大阪府吹田市山田丘2-6）
}

\title{
Prospect of Power Photonics
}

Masahiro NAKATSUKA

Institute of Laser Engineering, Osaka University, 2-6 Yamada-oka, Suita, Osaka 565-0871

生命, 地上で最も尊いものが現れ, 発展してきた時間に 比べると「一世紀」ぐらいと,ちょっと曲がって考えてしま いますが, 切机目にいろいろと内省してみることは必要な のでしょう．微分的に将来を認識することと, 積分的に過 去を考え直してみることが大切といいます.

研究者に与える言葉として, 以前に中国の研究所を訪ね たときに玄関先に(きっと政治的に偉い人の言葉として)書 かれていた揮毫を思い出しました，日本人の好きな言葉 の「がんばれ」に比べて「献身」や「自己犠牲」は私の年令では 懷かしく響きましたし、「先進」や「責任」は科学を再構筑す るときには心っくり考六入む姿勢を与えてくれました。 さて, レーザー研究の周辺を歩いてきた 30 年ほどを振り 返ってみると, 高出力レーザーは80年代の始めを区切りに 巨大科学に様変わりし,パワー光学と相互作用物理は広範 囲に展開を続けています. 光情報関連もインフラの充実 につれていよいよ価值の多様化に向けて驀進していま す.

極限の科学はその折々で常に先端科学でした。物性や 状態パラメー夕の極限を追って科学技術は進展し, 小さい 極限と大きな極限は相補的に発展してきました。量的極 限はその質の限界であって, 高次効果の出現や相変化によ り質的新領域へと導いてくれます. 光の科学でも極限的 な電磁場と電磁的物質の現実を地上実験でも手にできる 時代が到来しつつあります。

情報とエネルギーの流机密度の増大が, 素粒子宇宙から 生命までの自然世界の進化の方向を決定していると信じ ていますが,その意味でもパワーフォトニクスは新しい科 学技術的手段を我々に与えてくれます。情報の科学が複 雑系の科学, 統計的科学へと進み, エネルギーの科学が輻 射と物質の高エネルギー的共存状態の科学へと進展して いるのが現状です。

パワーフォトニクスは高平均・高ピーク出力光の発生 と制御, 伝播と集中, 物質との相互作用を体系的に扱う新
しい光工学です．従来の括りと異なって材料科学, 光学素 子技術, 熱工学, 光制御学, 線形コヒーレンス学, 非線形光 学, シミュレーション光学などを集大成し直してみる必要 があります、特徵は,レーザーの広帯域コヒーレンス性, 超 高周波性, 超高輝度性, 高エネルギー性などにあり, 結果と して精密制御, 高速制御, 遠隔制御, 高密度エネルギ一発生 と新規の相互作用などを生み出しています。光装置の複 雑化や多次元化と小型化は, 集積化によって矛盾無く達成 されなければなりませんが,ここにも突破不可欠のブレー クスルーの目標があります。

レーザー工学も成熟期を迎え, 要素としてのレーザー設 計だけでなく,単一ニーズを満たすトータルシステムの提 供が望まれています。応用面の広がりに連れ，さらに搪張 するためにも技術の成熟が望まれています，成熟した技 術は「先端技術」の定義から離れてゆきますが,成熟が質的 新規性を生み出すことで技術の成長は持続的になりま す. 集積化のキーワードは, 光の発生・制御では光の閉じ 込めに尽き, 装置製造では超精密 · 自動補正 · 複雑から単 純・自動組織化などで, 利用の面からはブラックボックス 化・維持作業不要化・小型化・自由連結などでしょう か.

パワーフォトニクスに対応する応用科学領域は「レー ザーエネルギー学」と呼んでいます. 超高出力・超高強度 レーザーの集光が新たな物質状態を作り,時間的に急速な 輻射場の立ち上がりが物質の各種応答速度をはるかに超 えたところに新物質状態の生成やその応用の新規性があ ります。既にX線発生とレーザー化, 粒子加速, 核融合研 究, 実験宇宙天文学などエネルギースケールの大きな新科 学領域が立ち上がりつつあり,超短パルスの物質処理など の生み出す新技術の産業応用への展開はまだよくは見え ていませんが, 新しいものを予感させ, 新世紀を迎えるに 当たって既に芽は出ているようです。 


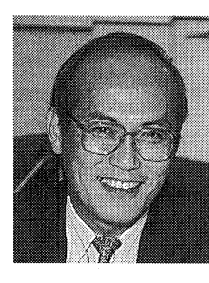

中塚 正大(正会員)

Masahiro NAKATSUKA

1966年大阪大学工学部電気工学科卒. 1973年同大学院工学研究科電気工学専攻 博士課程修了, 工学博士．同年4月近畿大 学理工学部助手, 1974年講師, 1979年助教 授.1980年大阪大学レーザー核融合研究センター助教授, 1993年教授。この間1987年フランス, エコールポリテク
ニーク客員研究員. 現在に至る. 当初, 炭酸ガスレーザー とその周辺技術に関する研究に従事, その後, 主に核融合 研究用ガラスレーザーシステム, 激光XII号の建設, 運転, 開 発に関する研究に従事. また,平均出力ガラスレーザーの開 発, レーザープラズマX線応用, 新レーザーガラスの研究, 補 償光学の研究をも併せ行っている. 電気学会, 応用物理学 会, レーザー医学会, OSA, SPIE各会員. 